\section{Venous Blood Derivatives as FBS- Substitutes for Mesenchymal Stem Cells: A Systematic Scoping Review}

Luiz A. Chisini', Marcus C.M. Conde2, Guillermo Grazioli, Alissa S. San Martin ${ }^{1}$, Rodrigo Varella de Carvalho ${ }^{4}$, Jacques E. Nör ${ }^{5}$, Flávio F. Demarco ${ }^{1}$

\begin{abstract}
Although the biological properties of mesenchymal stem cells (MSC) are well-characterized in vitro, MSC clinical application is still far away to be achieved, mainly due to the need of xenogeneic substances for cell expansion, such as fetal bovine serum (FBS). FBS presents risks regarding pathogens transmissions and internalization of animal's proteins, which can unleash antigenic responses in patients after MSC implantation. A wide range of venous blood derivatives (VBD) has been reported as FBS substitutes showing promising results. Thus, the aim of this study was to conduct a systematic scoping review to analyze whether VBD are effective FBS substitutes for MSC ex vivo expansion. The search was performed in SciVerse Scopus $^{\mathrm{TM}}$, PubMed, Web of Science ${ }^{\mathrm{TM}}$, BIREME, Cochrane library up to January 2016. The keywords were selected using MeSH and entry terms. Two independent reviewers scrutinized the records obtained considering specific inclusion criteria. The included studies were evaluated in accordance with a modified Arksey and 0' Malley's framework. From 184 found studies, 90 were included. Bone marrow mesenchymal stem cells (BMMSC) were presented in most of these studies. Overall, VBD allowed for either, maintenance of MCS's fibroblast-like morphology, high proliferation, high colony-formation ability and maintenance of multipotency. Besides. MSC expanded in VBD supplements presented higher mitogen activity than FBS. VBD seems to be excellent xeno-free serum for ex vivo expansion of mesenchymal stem cells. However, an accentuated heterogeneity was observed between the carried out protocols for VBD isolation did not allowing for direct comparisons between the included studies.
\end{abstract}

'Graduate Program in Dentistry, Dental School, UFPel - Universidade Federal de Pelotas, Pelotas, RS, Brazil ${ }^{2}$ Graduate Program in Dentistry, School of Dentistry, UNIVATES - Universidade do Vale do Taquari, Lajeado, Brazil

${ }^{3}$ School of Dentistry, Universidad de la República, Montevideo, Uruguay

${ }^{4}$ School of Dentistry, IMED

- Faculdade Meridional, Passo Fundo, RS, Brazil ${ }^{5}$ Department of Cariology, Restorative Sciences and Endodontics, School of Dentistry, University of Michigan, Ann Arbor, Ml, USA

Correspondence: Flávio Fernando Demarco, Rua Gonçalves Chaves 457, $5^{\circ}$ and., 96015-560 Pelotas, RS, Brasil. Tel: +55-53-98112-1141. e-mail: ffdemarco@gmail.com

Key Words: human serum, mesenchymal stem cells, platelet, venous blood derivatives, xeno-free.

\section{Introduction}

Mesenchymal stromal/stem cells (MSC) have been exhaustively investigated in vitro and due to high proliferative, self-renewal, immunomodulatory properties and multipotency, MSC present a high therapeutic potential to be applied in Stem Cell-Based Therapies (SC-BT) (1). Several strategies and approaches to use regenerative therapies in dentistry have been investigated (1-3), since that materials employed by the clinicians are, basically, synthetic (4-6) and can present limited ability to induce regeneration $(1,3,7)$. Thus, the use of MSC could improve the regenerative potential of bone, periodontal and dental pulp regenerative approaches. However, a recent scoping review evaluating the capacity of dental pulp tissue regeneration by strategies to revascularization of root canal has shown limited ability to promote regeneration (3) and this could be improved with the application of MSC. Although MSC's biological properties have been well-characterized in vitro, MSC clinical application is still far away to be achieved (8).

To be clinically applied, MSC must be previously isolated and expanded ex vivo in order to obtain a needed amount of cells, which will be replanted in patients $(8,9)$. Ex vivo MSC expansion relies on solutions composed by a basal medium, basically amino acids, vitamins and inorganic salts, which must be supplemented by Fetal Bovine Serum (FBS) $(10,11)$. FBS is the most applied supplement for MSC culture comprising a complex mixture of growth factors (GF), proteins, carbohydrates and cytokines indispensable for cell development and survival in vitro (12-14). However, FBS presents risks regarding pathogens transmissions and internalization of animal's proteins, which can unleash antigenic responses in the patient after MSC implantation $(9,15)$. Animal-derived (or xenogeneic) proteins can be detected in human MSC expanded in FBS, even after consecutive cell washings (9). Additionally, FBS induces changes in MSC surface markers and due to such characteristics. FBS must not be applied in humans (16).

To reduce the barriers arising from the use of xenogeneic materials and to allow the clinical acceptance of SC-BT, venous blood derivatives (VBD) has been widely considered to be applied as FBS substitutes (17-20). Venous blood is a source that can be easily obtained in a large volume from blood banks or from the own patient, decreasing the barriers for the use of SC-BT $(2,8,9)$. In contrast, umbilical cord blood is more difficult to obtain donors and provide few volume of blood available $(12,21$ 23). Therefore, VBD presetting an important source easily accessed to clinicians providing a potential xeno-free supplementation for MSC expansion $(24,25)$. In addition, a wide range of different serum/plasma blood derivatives has been reported as FBS substitutes showing promising results. Thus, the aim of this study was to conduct a scoping review to analyze whether VBD are effective FBS substitutes for MSC ex vivo expansion. 


\section{Material and Methods}

This study was designed following the modified fivestage framework proposed by Arksey and 0'Malley (26) denominated scoping review. Recently, several studies applied scoping review to state the current knowledge in a particular area when a systematic review cannot be conducted $(3,27)$. The scoping review design is indicated when the methodologies of studies present a considerable heterogeneity performing a qualitative analysis while a systematic review provides a quantitative analysis. A scoping review presents an exploratory research to respond a broader question through a systematized research, aiming to define concepts and mapping the methodologies used to define gaps in the literature to indicate the need for new studies. A scoping review was carried out to perform a knowledge synthesis regarding VBD as FBS substitutes for ex vivo MSC expansion. A complementary search was performed to identify the studies using MSC in humans expanded in VBD.

\section{Conceptual Definition}

According to MeSH database (http://www.ncbi.nlm.nih. gov/mesh), serum is defined as "The clear portion of blood that is left after blood coagulation to remove blood cells $\vec{\Xi}$ and clotting proteins by centrifugation". In the meantime, plasma is defined as "the residual portion of blood that is left after removal of blood cells by centrifugation without prior blood coagulation". Unlike plasma, serum naturally contains platelet-derived molecules, such as $\alpha$-granulesderived growth factors, which become available exclusively after platelet-activation. For Human Serum (HS) the whole blood is collected in an anticoagulant-free plastic bag and stored overnight $\left(4^{\circ} \mathrm{C}\right)$, or at the end of shelf-life, to allow for blood coagulation. Right after, the formed clot must be centrifuged (3000 rpm for $5 \mathrm{~min}$ ) in order to obtain a supernatant, corresponding to HS (21). PlateletRich Plasma (PRP) is stated as "A preparation consisting of platelets concentrated in a limited volume of plasma". While the natural-formed blood clot contains $95 \%$ of red blood cells, $5 \%$ platelets, less than $1 \%$ white blood cells and fibrin strands, PRP holds 4\% red blood cells, 95\% platelets and $1 \%$ white blood cells (28). PRP should be chemically activated by the addition of human/bovine thrombin or Calcium Chloride - $\mathrm{CaCl}_{2}$, affording activated PRP -aPRP $(24,25,29)$. To obtain PRP, whole anticoagulated blood, must be submitted to a double-centrifugation; the first one (soft spin) results in a three-layer suspension where the red blood cells are found at the bottommost layer. Both, topmost, named platelet-poor plasma (PPP), and intermediate (PRP) layers should be transferred to another tube without anticoagulant. Thus, the second spinning (hard spin) is performed, to allows platelets settle the bottom of tube. Then, superficial layer is discarded and the remaining material (PRP) is shaken. To release its platelet content, PRP must be activated (aPRP) by the addition of human/bovine thrombin or Calcium Chloride $\left(\mathrm{CaCl}_{2}\right)$ $(24,25)$. Human Platelet Lysate (HPL) results from a lysis of high platelet concentrate (traditionally the PRP), being the platelet mechanical lysis induced by susceptive freeze-thaw cycles at -80 or $-20{ }^{\circ} \mathrm{C}$ (typically 2 or 3 cycles). Thus, the platelet debris must be separated from the clear portion containing platelet released by centrifugation.

\section{Information Sources, Literature Search and Inclusion Criteria}

A structured search was performed in SciVerse Scopus ${ }^{\mathrm{TM}}$, PubMed/Medline, ISI Web of Science ${ }^{\mathrm{TM}}$, and BIREME up to January 2016. The relevant MeSH terms and entry terms (Table 1) were selected based on the PICO-structured

Table 1. Structured search strategy carried out in MEDLINE/PubMed database. The search followed structural of each database

Search Syntaxes

"mesenchymal stromal cells”[MeSH Terms] OR (“mesenchymal”[All Fields] AND "stromal”[All Fields] AND "cells"[All Fields]) OR "mesenchymal stromal cells"[All Fields] OR ("mesenchymal”[All Fields] AND “stem”[All Fields] AND “cells”[All Fields]) OR “mesenchymal stem cells”[All Fields]

"Culture Media, Serum-Free"[All Fields] OR “Culture Media, Serum Free”[All Fields] OR ("culture media, serum-free”[MeSH Terms] OR ("culture"[All Fields] AND "media”[All Fields] AND "serum-free"[All Fields]) OR "serum-free culture media”[All Fields] OR ("media”[All Fields] AND "serum"[All Fields] AND "free”[All Fields] AND "culture"[All Fields])) OR "Serum-Free Culture Media”[All Fields] OR “Serum-Free Media”[All Fields] OR "Media, Serum-Free"[All Fields] OR "Serum Free Media”[All Fields] OR "Protein-Free Media”[All Fields] OR ("culture media, serum-free"[MeSH Terms] OR ("culture”[All Fields] AND "media”[All Fields] AND "serum-free"[All Fields]) OR "serum-free culture media”[All Fields] OR ("media”[All Fields] AND "protein”[All Fields] AND “free"[All Fields])) OR "Protein Free Media”[All Fields] OR "Low-Serum Media”[All Fields] OR "Low Serum Media”[All Fields] OR (“culture media, serum-free”[MeSH Terms] OR (“culture”[All Fields] AND "media”[All Fields] AND "serum-free”[All Fields]) OR “serum-free culture media”[All Fields] OR ("media”[All Fields] AND “low”[All Fields] AND “serum”[All Fields]))

"Platelet lysate"[All Fields] OR “thrombin activated platelet”[All Fields] OR (allogenic[All Fields] AND pooled[All Fields] AND ("humans"[MeSH Terms] OR "humans"[All Fields] OR "human"[All Fields]) AND ("serum"[MeSH Terms] OR “serum”[All Fields])) OR “pooled human serum”[All Fields] OR “autologous serum”[All Fields] OR "human serum”[All Fields] OR “thrombin activated platelet”[All Fields] OR "pooled human platelet lysate”[All Fields] OR "platelet rich plasma”[All Fields] 
question "Could human venous blood derivatives be applied as FBS substitutive for MSC ex vivo expansion?", where:

- P: Human MSC

- I: human serum; Platelet Rich Plasm; Activated Platelet-Rich Plasm; Human Platelet lysate; Plasma; Platelet Poor Plasma; Human Plasm

- C: Fetal Bovine Serum

- $\quad$ 0: MSC biological properties: Cell viability, cell proliferation, multipotency, population doubling time, senescence, telomere shortening

The retrieved records were uploaded into the EndNote ${ }^{\mathrm{TM}}$ software, aiming to delete duplicates and to build up a virtual library (VL). Two independent reviewers (LAC and MCMC) read the titles and abstracts of all reports, under predefined inclusion criteria (Table 2). To confirm if the selected studies met the inclusion criteria, the same reviewers independently judged each full text. If any disagreement was found, the reviewers attempted to reach a consensus through discussions. Persistent disagreements have been decided by an intervention from the third reviewer (FFD). Thus, manual evaluation of references from each evaluated study was performed. Twenty percent of the studies were randomly raffled, and the data have been again checked.

Search to identify clinical application of cell therapy using blood derivate serums: The literature was investigated using the keywords: "clinical study", "mesenchymal stem cell", "serum-free medium", "Platelet lysate", "human serum" and "autologous serum" for identify studies employing cell therapy in humans with ex vivo expansion in medium supplemented with VBD, to provide an overview of clinical application.

\section{Results}

The initial search yielded 272 records corresponding to 184 studies (Table 3 ). After preliminary titles and abstracts evaluation, 102 studies were select for full-text assessment (Fig. 1). Ninety papers were designated for data extraction.

Table 2. Criteria for selection of the studies

\begin{tabular}{lcc}
\hline & Inclusion Criteria & Exclusion criteria \\
\hline Studies & $\begin{array}{c}\text { Original papers in } \\
\text { vitro and in vivo }\end{array}$ & Reviews \\
Language & $\begin{array}{c}\text { English, Spanish, Italian, } \\
\text { French, and Portuguese }\end{array}$ & Other languages \\
Cell type & Human MSC & not human MSC \\
& $\begin{array}{c}\text { Human serum and plasma; } \\
\text { platelet lysate; thrombin- } \\
\text { VBD from }\end{array}$ & Umbilical cord \\
& $\begin{array}{c}\text { activated platelet release in } \\
\text { plasma; platelet rich plasma }\end{array}$ & \\
Aim & VBD as FBS substitute & \\
\hline
\end{tabular}

Excluded studies (10,30-40) and reasons are described in Table 4. Most of the included studies described protocols relying on the platelets lyse after freeze-thaw cycles to obtain VBDs. Bone marrow mesenchymal stem cells (BMSC) were presented in most of this studies (Table 5); adipose stem cells - ASC $(24,41-46)$, dental pulp stem cells - DPSC (47,48), umbilical cord stem cells - UCST $(22,25,49-52)$ and orbital fat-derived stem cells (53) were also tested. VBD concentrations added to culture medium ranged from 0.5 to $30 \%$ (54-56). Overall, VBD allowed for either, maintenance of MCS's fibroblast-like morphology $(17,43,57)$, high proliferation (58-60), high colony-formation ability $(52,61,62)$ and maintenance of multipotency (63-67). A linear dose-dependent response regarding medium concentration was not observed for evaluated VBD $(54,56,68)$.

Human platelet lysate (HPL): HPL showed a higher osteogenic potential than MSC in FBS $(55,69,70)$. Besides, MSC expanded in HPL seems presented immunomodulatory ability $(52,55,71,72)$ despite a decrease of ability of inhibition NK and T-cells has also been observed (73). Platelets lyse was triggered by either, freeze-thaw cycles (1 to 5), ultrasound (63) or chemical treatment (43). HPL presented a high growth factors and cytokines content (74-77). HPL seemed to be better than FBS for ex vivo MSC expansion $(52,72,78,79)$ since HPL-expanded MSC did not present telomerase shortening (68).

Human Serum (HS): Overall, HS allowed for the isolation and expansion of BMSC, ASC, DPSC maintaining proper cell biological properties both in vitro and in vivo $(48,80-85)$. Both, $10 \%$ HS in DMEM/F-12 or $5 \%-10 \%$ HS in $\alpha M E M$ provided, to ASC and BMMSC, proliferation rates and multipotency as higher as $10 \%$ FBS $(24,48,51,86-88)$.

Platelet-rich plasma: Platelets form PRP has been activate with trombin or calcium chloride aiming the increase of bioactive molecules release $(24,29,89)$, however similar properties were observed in PRP (10\% freeze thawed human PRP $(49,91)$ / with platelet concentration $(92,93)$ / platelet and leukocytes concentration (90)). PRP (5\% or 10\%)-supplemented media heat-inactivated (platelet concentration $79.6 \times 10^{4} / \mu \mathrm{L}$ ) provided similar results for adipogenic and osteogenic differentiation when compared to $10 \%$ FBS (92). Besides, PRP supplemented aMEM also provides osteogenenic, chondrogenic and adipogenic differentiation promoting an increase of cell culture

Table 3. Records recovered in each database

\begin{tabular}{ccccc}
\hline PubMed $^{\circledR}$ & Scopus $^{\circledR}$ & $\begin{array}{c}\text { ISI web of } \\
\text { science }\end{array}$ & $\begin{array}{c}\text { Cochrane } \\
\text { library }\end{array}$ & $\begin{array}{c}\text { BVS } \\
\text { Bireme }^{\circledR}\end{array}$ \\
\hline 64 & 121 & 68 & 0 & 19 \\
\hline
\end{tabular}


proliferation $(22,49)$. In this way, 10\% aPRP (platelets concentered) has been reported as providing similar (25), or higher proliferation rates than FBS (89). In addition, only in one study reported the presence of leukocyte into PRP $\left(0.3 \times 10^{4} \mathrm{~mL}\right)(90)$. Strategies to decreased leukocyte in the PRP even as assessment of activation by flow cytometry did not were reported on included studies. Other VBD: MSC were also expanded by applying platelet-poor plasma (PPP) (94), fresh frozen platelet plasma (FFPP) $(56,95)$ and HS obtained from PPP (42). Either MSC expanded in PPP, FFPP and in FBS had the same phenotype for antigens CD73,
CD90, CD105, CD14, CD19, CD34, CD45, HLA-DR. Such MSC presented osteogenic, adipogenic and chondrogenic differentiation and were able to survive in a fibrin clot. BMSC expanded in culture medium containing high (20 and $30 \%$ ) and low (1\%) FFPP concentrations, produced insufficient calcified matrix (56).

Human studies: Seven studies employed MSC expanded in VBD for tissue regeneration (96-102). HPL and HS were used for MSC expansion for clinical application. These studies did not observe neither signal of malign transformation nor some complication associated with HPL or HS.

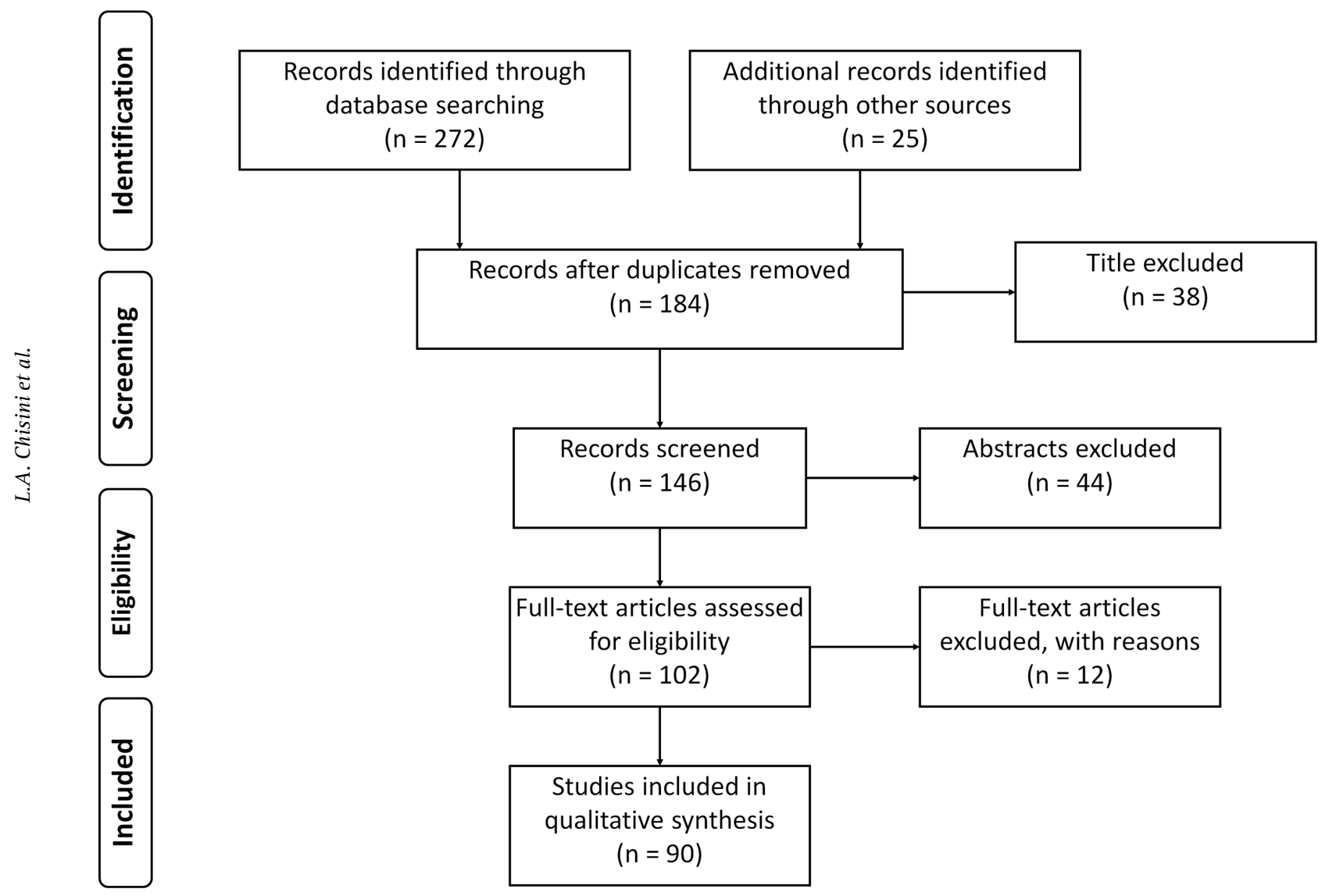

Figure 1. Flow Diagram

Table 4. Excluded studies and reasons for exclusion

Studies $\quad$ Reason

Cheng et al. (30); Jung et al. (10); Dolley-Sonneville et al. (32); Mark et al. (33); Reza et al. (34); Sato et al. (35); Tan et al. (36); Trubiani et al. (37)
Not defined venous blood derivative serum 
Table 5. Included studies and respective VBD supplements and concentrations, concentration of FBS and stem cells utilized

\begin{tabular}{|c|c|c|c|}
\hline Author & Xeno-free evaluated and concentration & $\begin{array}{l}\text { Contol and } \\
\text { concentration }\end{array}$ & Stem Cells \\
\hline Stute et al. (21) & $1 \%, 3 \%$, and $10 \% \mathrm{HS}$ & $10 \% \mathrm{FBS}$ & BMSC \\
\hline Doucet et al. (62) & 5\% HPL & $10 \%$ FBS & BMSC \\
\hline Shahdadfar et al. (80) & $20 \% \mathrm{HS}$ & FBS $20 \%$ & BMSC \\
\hline Gregory et al. (81) & $20 \% \mathrm{HS}$ and $10 \% \mathrm{HS}+$ grow factors & FBS $20 \%$ & BMSC \\
\hline Muller et al. (95) & $2.5 \%$ and $5 \%$ HPL & $10 \%$ FBS & BMSC \\
\hline Vogel et al. (111) & $3 \%$ PRP & FBS $2 \%$ & BMSC \\
\hline Le Blanc et al. (82) & $10 \% \mathrm{HS}$ & $10 \%$ FBS & BMSC \\
\hline Capelli et al. (60) & 5\% HPL & FxBS $10 \%$ & BMSC \\
\hline Kocaoemer et al. (89) & $10 \%$ HS and $10 \%$ aPRP & $10 \%$ FBS & ASC \\
\hline Lange et al. (78) & $5 \% \mathrm{HPL}$ & $10 \% \mathrm{FBS}$ & BMSC \\
\hline Lataillade et al. (102) * & 8\% HPL & - & BMSC \\
\hline Reinisch et al. (72) & 10\% HPL & $10 \%$ FBS & UCMSC and BMSC \\
\hline Schallmoser et al. (75) & $10 \% \mathrm{HPL}$ & $10 \% \mathrm{FBS}$ & BMSC \\
\hline Schallmoser et al. (114) & $5 \%$ and $10 \% \mathrm{HPL}$ & $10 \%$ FBS & BMSC \\
\hline Shayesteh et al. (97) * & $20 \% \mathrm{HS}$ & - & BMSC \\
\hline Zaky et al. (70) & $5 \% \mathrm{HPL}$ and $5 \% \mathrm{HPL}+10 \% \mathrm{FBS}$ & 10\% FBS and FGF2 & BMSC \\
\hline Behnia et al. (99) & $20 \%$ HS & - & BMSC \\
\hline Bieback et al. (29) & $10 \%$ aPRP and $10 \% \mathrm{HPL}$ and $10 \% \mathrm{HS}$ & $10 \% \mathrm{FBS}$ & BMSC \\
\hline Blande et al. (64) & $2.5 \%$ or $10 \% \mathrm{HPL}$ & $10 \%$ FBS & ASC \\
\hline Lindroos et al. (86) & $10 \% \mathrm{HS}$ & $\begin{array}{l}\text { 10\% FBS or } \\
\text { StemPro }{ }^{\circledR}\end{array}$ & ASC \\
\hline Kishimoto et al. (84) & $\begin{array}{l}8 \% 4 \% 2 \%, 1 \%, 0.5 \% \text { HS with } \mathrm{FGF}_{2} \\
5 \mathrm{ng} / \mathrm{mL} \text { (F/P MP-Coated plates) }\end{array}$ & not coated HS & BMSC \\
\hline Pytlik et al. (88) & $10 \% \mathrm{HS}$ & $10 \%$ FBS & BMSC \\
\hline Schallmoser et al. (20) & 10\% HPL & - & MSC \\
\hline Bieback et al. (24) & $10 \%$ HS and $10 \%$ aPRP & $10 \% \mathrm{FBS}$ & ASC \\
\hline Centeno et al. (101) * & 10-20\% HPL & - & BMSC \\
\hline Chevallier et al. (59) & 5\% HPL & $10 \% \mathrm{FBS}$ & BMSC \\
\hline Felka et al. (56) & $\begin{array}{l}\text { FFP with platelet concentrate } 0.5,1 \%, 5 \%, 10 \%, 20 \% \text { and } 30 \% \\
\text { and human plasma-enriched with platelets media 5\% and 10\% }\end{array}$ & $10 \% \mathrm{FBS}$ & BMSC \\
\hline Hartmann et al. (51) & $2 \% \mathrm{HS}$ & FBS & UCMSC \\
\hline Horn et al. (69) & 10\% HPL & $10 \% \mathrm{FBS}$ & MSC \\
\hline Ichiyanagi et al. (94) & Platelet poor plasma $5 \%, 10 \%$ and $20 \%$ & $10 \%$ FBS & BMSC \\
\hline Lindroos et al. (87) & $10 \%, 15 \%$ and $20 \% \mathrm{HS}$ & $10 \%$ FBS & ASC \\
\hline Lucchini et al. (100) * & 5\% HPL & - & MSC \\
\hline Salvade et al. (77) & 5\% HPL & $10 \% \mathrm{FBS}$ & BMSC \\
\hline Abdelrazik et al. (73) & $10 \% \mathrm{HPL}$ & $10 \% \mathrm{FBS}$ & MSC \\
\hline Aldahmash et al. (85) & $2.5 \%, 5.0 \%$ and $10.0 \% \mathrm{HS}$ & $10 \%$ FBS & BMSC \\
\hline Capelli et al. (108) & 5\% HPL & - & UCSC \\
\hline
\end{tabular}


Cholewa et al. (41)

Crespo-Diaz et al. (109)

Flemming et al. (71)

Goedecke et al. (92)

Govindasamy et al. (47)

Hatlapatka et al. (50)

Jenhani et al. (65)

Shih et al. (43)

Venugopal et al. (106)

Xia et al. (76)

Jenhani et al. (65)

Behnia et al. (96) *

Fekete et al. (12)

Fekete et al. (13)

Gottipamula et al. (54)

Kishimoto et al. (93)

Kruger et al. (90)

Lohmann et al. (61)

Murphy et al. (22)

Pisciotta et al. (48)

Poloni et al. (113)

Stehlik et al. (11)

Bernardi et al. (63)

Griffiths et al. (68)

Hemeda et al. (117)

Trojahn Kolle et al. (107)

Kyllonen et al. (45)

Mojica-Henshaw et al. (118)

Pawitan et al. (83)

Rojewski et al. (120)

Sandor et al. (98) *

Schallmoser et al. (58)

Shanskii et al. (74)

Castiglia et al. (23)

Fekete et al. (14)

Gottipamula et al. (104)

Iudicone et al. (66)
$1 \%, 2.5 \%, 5 \%, 10 \%$, and $20 \%$ HPL

5\% HPL

$10 \%$ HPL

$5 \%$ and $10 \%$ PRP

10\% HPL

HS 2\%, 5\%, 10\% and HS 2\% with 0.5 ng/mL FGF

$5 \%, 10 \%$ HPL or $5 \%$ HPL and 10\% FBS or $10 \%$ HPL and $10 \%$ FBS

$$
\text { 10\% HPL }
$$

5\% HS and $2 \mathrm{ng} / \mathrm{mL}$ bFGF

$$
\text { 7.5\% HPL }
$$

5\%,10\% HPL

$10 \%$ FBS

$5 \% \mathrm{HPL}$

$20 \%$ HS

2.5\%, 5\%, 10\%, 15\% and 20\% HPL

$10 \%$ HPL

10\% HPL (5 to 20\% preliminary screening)

$$
\begin{aligned}
& 4 \%, 2 \%, 1 \% \text { and } 0.5 \% \text { PRP } \\
& \text { or } 4 \%, 2 \%, 1 \% \text { and } 0.5 \% \text { HS }
\end{aligned}
$$

10\% HS and 5\% PRP

10\% HPL

$1 \%$ or $10 \%$ PRP

$10 \% \mathrm{HS}$

5\% HPL and HS 10\%

$10 \%$ HS

10\% HPL

2\%, 5\% and 10\% HPL

$10 \%$ HPL

10\% HPL

$10 \% \mathrm{HS}$

10\% HPL

5\% and 10\% PRP

$5 \%$ and $10 \% \mathrm{HS}$

10\% HPL

15\% HS

10\% HPL

$10 \% \mathrm{HPL}$

FBS/HPL ratios: 10/0, 7.5/2.5, 5.0/5.0, 2.5/7.5, and 0/10)

10\% HPL

5\%, 10\% and 20\% HPL

$5 \%, 10 \%$ and $20 \% \mathrm{HS}$

$2.5 \% \mathrm{HS}$

10\% HPL

$\begin{array}{cc}\text { FBS } 1 \%, 2.5 \%, 5 \%, & \text { ASC } \\ 10 \% \text {, and } 20 \% & \\ 10 \% \text { FBS } & \text { BMSC and ASC } \\ 10 \% \text { FBS } & \text { BMSC } \\ 10 \% \text { FBS } & \text { BMSC } \\ 10 \% \text { FBS } & \text { DPSC } \\ \text { FBS } & \text { UCMSC }\end{array}$

BMSC and UCMSC

ASC

$10 \%$ FBS

WJSC

BMSC

10\% FBS $1 \mathrm{ng} / \mathrm{mL}$

fibroblast growth factor 2 (FGF2)

BMSC

BMSC

FBS 20\%

BMSC

BMSC

10\% FBS

BMSC

BMSC and ASC

CSSC

10\% FBS

BMSC

10\% FBS

UCMSC

$10 \%$ FBS

DPSC

FBS 20\%

CVMS and BMSC

BMSC

10\% FBS

BMSC

BMSC

BMSC and ASC

10\% FBS

ASC

$10 \%$ FBS

ASC

10\% FBS

MSC

ASC

10\% FBS

BMSC

ASC

10\% FBS

MSC

FBS

MSC

10\% FBS

BMSC

FBS 5\%, 10\% and $20 \%$

BMSC

10\% FBS

BMSC

10\% FBS

BMSC 
Koellensperger et al. (42)

Martins et al. (53)

Muraglia et al. (19)

Pham et al. (25)

Yamauchi et al. (79)

Antoninus et al. (17)

Budiyanti et al. (49)

Jonsdottir-Buch et al. (15)

Laitinen et al. (55)

Laner-Plamberger et al. (67)

Li et al. (57)

Luzzani et al. (52)

Oikonomopoulos et al. (46)

Paula et al. (44)

Pawitan et al. (91)

Riordan et al. (105)
Castren et al. (18)
HS 2\%, 10\%; PPP 2\%, 10\%; PL 2\%, 10\%

$10 \%$ HS

5\% HPL

2\%, 5\%, 7\% and 10\% aPRP

5\% HPL

HPL $0.031 \mathrm{mg} / \mathrm{mL}, 0.063 \mathrm{mg} / \mathrm{mL}, 0.125$ $\mathrm{mg} / \mathrm{mL}$, and $0.250 \mathrm{mg} / \mathrm{mL}$

PRP 10\%

AB-plasma 2.5\% + HPL 0.5\%

10\% HPL

5\% and 10\% HPL

10\% HPL

5\% HPL

10\% HPL

10\% HPL

HS 10\%

PRP 10\%

5\%, 7.5\% and 10\% HPL

\begin{tabular}{cc}
$10 \%$ FBS & ASC \\
$10 \%$ FBS & OFSC \\
$10 \%$ FBS & BMSC \\
$10 \%$ FBS & UCMSC \\
$10 \%$ FBS & BMSC \\
$20 \%$ FBS & WJSC \\
MesenCult ${ }^{\circledR}$ & UCSC \\
$10 \%$ FBS & BMSC \\
- & BMSC \\
$10 \%$ FBS & BMSC \\
$10 \%$ HPL & BMSC and UCMSC \\
- & BMSC and ASC \\
$10 \%$ FBS & UCMSC and iPS \\
$10 \%$ FBS & BMSC and ASC \\
$10 \%$ FBS & ASC \\
$10 \%$ FBS & BMSC \\
$10 \%$ FBS & WJSC \\
\hline
\end{tabular}

* MSC expanded in VBD for tissue regeneration in humans. MSC: mesenchymal stem cells; UCSC: umbilical cord derived mesenchymal stem cells; ASC: adipocyte stem cells; BMSC: bone marrow stem cells; WJSC: Wharton's Jelly-derived stem cells; OFSC: orbital fat-derived stem cells; CVMS: chorionic villi-derived stem cells; DPSC: dental pulp stem cells; CSSC: human cortico-spongious stem cells; FFP: fresh frozen plasma.

\section{Discussion}

The recent literature has been investigated FBS substitutes for MSC ex vivo expansion aiming to eliminated the risks inherent to xenogeneic agents for clinical translation of regenerative therapies $(103,104)$. In this systematic scoping review, the studies evaluating VBD as FBS substitutes were summarized. Overall, different protocols were developed and tested to obtain a FBS substitute able to maintain MSC in vitro, preserving stemness and multipotency $(103,105)$. VBD were promissors as FBS substitutes, since senescence $(68,106)$ or Karyotype/ chromosomal alteration were not detected in MSC expanded in VBD (13,23,107-109). In addition, clinical studies strengthened such evidence by reporting none malign transformation in vivo $(96,99,101,102)$.

Despite blood of umbilical cord possess a higher amount of growth factors (platelet-derived growth factors -PDGF, fibroblast growth factor 2 -FGF-2 and vascular endothelial growth factor -VEGF) when compared to venous blood, the application of blood from umbilical cord is restricted due the difficult to obtain large volumes (12,21-23). Besides, the growth factors concentration found in different VBD $(12,22,110)$ was reported as higher than in $\mathrm{FBS}(22,41,43,111)$. Autologous and homologous blood have been presented a high amount of platelets, which contains the growth factors responsible VBD therapeutic potential (112). During platelet activation biomolecules such as insulin-like growth factor (IGF), PDGF, transforming grow factor $\beta$ (TGF- $\beta$ ), and other molecules such as thrombospondin and fibronectin are released (112). HPL presented high concentrations of endothelial growth factor (EGF), PDGF, TGF- $\beta$, fibroblast growth factors $\beta$ (FGF- $\beta$ ) and VEGF when compared to HS (110). Furthermore, the low proteic content observed in HPL may be beneficial by decreasing the risk of immunological reactions for allogenic blood-derived (110). The platelets lyse seems to release all platelet-derived growth factors available, which could not happen during blood coagulation (103). Nonetheless, Poloni (113) showed HS inducing higher cell proliferation than $\mathrm{HPL}$, contrary to the expected. Even so, both were better than FBS.

MSC expanded in VBD supplements have presented major mitogen activity than FBS (8) despite several protocols and concentrations being tested, decreasing larger comparisons. 10\% HS-expanded DPSC presented lower initial proliferation rate and population doubling time (PDT) until the fourth day, when compared to $10 \%$ FBS-expanded MSC. After the fourth day, an increase in proliferation of cells under HS 10\% was reported. HS 10\% expanded DPSC were capable of regenerating more mineral tissue than those 10\% FBS-expanded in vivo 
(48). The studies reported 5\% (68) and 10\% (12) as being the optimal HPL concentration range for MSC expansion $(12,54,64,114)$. Moreover, different VBD concentration $(0.5-30 \%)$ have been tested presenting different results, which have not been necessarily dose-dependent (54-56). Overall, the selected studies indicated VBD concentrations ranging from $5 \%$ to $10 \%$ by presenting good results to be applied as FBS substitutive $(8,21,25,56,94)$.

DMEM is currently applied for MSC isolation and expansion $(1,5,115,116)$; DMEM calcium content can stimulate a polymerization of fibrin present in $\mathrm{HPL}$, thereby forming a gel into the solution (8). To avoid this, fibrinogen or heparin has been applied (69). Despite almost studies use 1 or $2 \mathrm{IU} / \mathrm{mL}$ heparin, Hemeda, Giebel (8) demonstrated that $0.61 \mathrm{IU} / \mathrm{mL}$ or $0.024 \mathrm{mg} / \mathrm{mL}$ for low-molecular-weight heparin was sufficient to avoid gel formation. However, high heparin concentrations seem to reduce adipogenic and osteogenic differentiation, as well as cell proliferation (117). In the protocol to obtain the HPL, the Induction of fibrin clotting formation with calcium chloride (instead of thrombin) and posterior centrifugation provides a serum with the same profile of growing factor and cytokines than conventional HPL activated with thrombin, resulting $\vec{s}$ in a serum without free of xenogeneic substances such as porcine thrombin (118). HPL supplemented without anticoagulants tend to form a translucent and viscous gel in $1 \mathrm{~h}$ providing a natural scaffold for MSC culture and expansion (61). This matrix, composed by a fibrin network, was biocompatible and biodegradable. Additionally, MSC cultured in this fibrin matrix presented higher proliferation since growth is available in three-dimensional environment, increasing the culture area $(8,61)$.

Interesting findings have been observed regarding to trypsin kinetics of MSC supplemented with VBD. MSC expanded in HS or HPL have been trypsinized with $0.05 \%$ Trypsin/EDTA, instead the conventional $0.25 \%$ applied for MSC culture in FBS. VBD supplementation provides a decrease in production of adhesion proteins $(54,94)$. An ASC genome gene expression analysis depicted 102 genes were commonly expressed in differentiated ASC being 90 genes, including those responsible for MSC adhesion, high expressed in 10\% FBS-supplemented ASC (24), which may be connected to high sensitivity presented to trypsin by MSC expanded in VBD. Changes in surface markers expression has been contradictorily reported in VBD-expanded MSC $(25,49,50,92)$. HS and aPRP provided maintenance of MSC immunophenotype (25).

Currently it is clear that the number of passages reduces MSC differentiation potential and the capacity of proliferation conducting to function alteration (119). MSC senescence has been the focus of some selected studies $(41,44,68,106)$. $\beta$-galactosidase, a biomarker for cell senescence, was expressed strongly in FBS cultures when compared with HPL up to 16 passages (68). On the other hand, Venugopal, Balasubramanian (106) showed similar senescence rates for MSC expanded in HS or FBS. Besides, the age of VBD-donor could influence MSC senescence however, controversial results have been described $(61,110)$. MSC expanded in HS from older donors ( $>45$ years old) presented higher $\beta$-galactosidase expression than MSC from younger donors ( $<35$ years old) ( 54$)$. However, donors' age did not influence the GF concentration, hormones content of MSC expanded in HPL (61). Individual variations are expected in VBD, principally in plasm components. Blood contains several components as lipids (HDL, cholesterol), proteins, metabolites of uric acid, creatinine, and albumin; even as several ions: calcium, potassium, resulting from individual diet. Thus, plasm portion may have changes in biochemical composition (74). Growth factor's release profile of HPL and HS were contrasting. HPL seems to contain higher amounts of PDGF, VEGF, EGF, FGF- $\beta$, TGF- $\beta$ and less insulin like growth factor 1 (IGF-1) than HS (110).

A high variation between carried out protocols as well as in the methodologies was detected in the selected studies. Thus, evaluation of quality of the methodologies thought available tools is not possible. However, some points can be highlight about the quality of methodologies. The majority of studies present a high control of surface markers before and after the use of VBD showing the differentiation in almost three cell lineages. Besides, selected studies present control groups (positive and negative) to compare statistically the results. However, variables such as, steps applied to obtain VBD, centrifugation times and culture medium applied were superficially described in the selected studies, which did not allow for direct comparisons between the included studies. In addition, few studies performed a direct comparison between different VBD in the same study. In such a context, it is strongly recommended to perform well-designed randomized controlled trials comparing different VBD obtaining protocols. Besides, protocols standardization should be considered to perform such comparisons.

Although the literature shows a wide variation between methodological studies, VBD presented excellent results as substitute to FBS, seeming to be a supplementation option for MSC in SC-BT. The substitution of animal compounds is highly recommended for good manufacturing practices (GMP) $(13,120)$ guidelines, eliminating the need for animal additives for regenerative therapies in humans (96-102). VBD-supplemented MSC were applied for sinus lift augmentation (97), regeneration of alveolar clefts (96), even as regeneration of large anterior mandibular defect (98) and radiation burn treatment (102). Centeno, Schultz (101) used MSC supplemented in HPL (339 patients) to treat different 
orthopedic conditions. Neoplasic transformations were not reported after 3 years of follow-up. Besides, Lucchini, Introna (100) realized an administration of intravenous MSC (expanded in 5\% HPL) in eleven patients. However, such clinical results corroborate with in vitro and in vivo data, showing safe application of expanded MSC in humans. It is important to highlight that no malignant transformation was reported in such studies.

Venous blood derivatives seem to be excellent xeno-free serum for ex vivo expansion of mesenchymal stem cells. The replacement of Fetal Bovine Serum by venous blood derivatives can be an important step towards the translation of stem cell-based therapies to the clinic.

\section{Resumo}

Embora as propriedades biológicas das células-tronco mesenquimais (MSC) sejam bem caracterizadas in vitro, a aplicação clínica das MSC ainda está longe de ser alcançada, principalmente devido à necessidade de substâncias xenogênicas para expansão celular, como o soro fetal bovino (FBS). 0 FBS apresenta riscos quanto às transmissões de patógenos e à internalização de proteinas animais, o que pode desencadear respostas antigênicas em pacientes após a implantação das MSC. Uma vasta gama de derivados do sangue venoso (VBD) têm sido relatada como substitutos do FBS mostrando resultados promissores. Assim, o objetivo deste estudo foi conduzir uma revisão de escopo sistemática para analisar se VBD poderiam ser substitutos do FBS eficazes para expansão das MSC em condições ex vivo. A pesquisa foi realizada no SciVerse Scopus, PubMed, Web of Science, BIREME e biblioteca Cochrane até janeiro de 2016. As palavras-chave foram selecionadas usando MeSH e entre termos. Dois revisores independentes examinaram os registros obtidos considerando critérios de inclusão específicos. Os estudos incluídos foram avaliados de acordo com uma estrutura modificada de Arksey e 0 'Malley. Dos 184 estudos encontrados, 90 foram incluidos. As células-tronco da medula óssea (BMMSC) foram utilizadas na maior parte destes estudos. Em geral, o VBD permitiu tanto a manutenção da morfologia semelhante a fibroblastos das MCS, alta proliferação, alta capacidade de formação de colônias e manutenção de multipotêncialidade. Além disso, as MSC expandidas em suplementos derivados do sangue venoso apresentaram uma maior atividade mitogênica do que as expandidas em FBS. Os VBD parecem ser excelentes soro livres de agentes xenogênicos para expansão ex vivo de MSC. Entretanto, observou-se uma heterogeneidade acentuada entre os protocolos realizados para o isolamento VBD, não permitindo assim comparações diretas entre os estudos incluidos.

\section{References}

1. Conde MC, Chisini LA, Demarco FF, Nor JE, Casagrande L, Tarquinio SB. Stem cell-based pulp tissue engineering: variables enrolled in translation from the bench to the bedside, a systematic review of literature. Int Endod J 2016;49:543-550.

2. Chisini L, Karam S, Noronha T, Sartori L, San Martin A, Demarco F, et al.. Platelet-poor plasma as a supplement for fibroblasts cultured in platelet-rich fibrin. Acta stomatol Croat 2017;51:133-140.

3. Conde MC, Chisini LA, Sarkis-Onofre R, Schuch HS, Nor JE, Demarco FF. A scoping review of root canal revascularization: relevant aspects for clinical success and tissue formation. Int Endod J 2016;50:860-874.

4. Chisini LA, Conde MC, Correa MB, Dantas RV, Silva AF, Pappen FG, et al.. Vital pulp therapies in clinical practice: findings from a survey with dentist in Southern Brazil. Braz Dent J 2015;26:566-571.

5. Demarco FF, Conde MC, Cavalcanti BN, Casagrande L, Sakai VT, Nor JE. Dental pulp tissue engineering. Braz Dent J 2011;22:3-13.

6. De Carvalho RV, Chisini LA, Ferrua CP, Guiraldo RD, Gonini-Junior $A$, Moura SK, et al.. The influence of concentration of HEMA on degree of conversion and cytotoxicity of a dental bonding resin. Minerva Stomatol 2016;65:65-71.

7. Alcazar JC, Salas MM, Conde MC, Chisini LA, Demarco FF, Tarquinio SB, et al.. Electrochemical cathodic polarization, a simplified method that can modified and increase the biological activity of titanium surfaces: a systematic review. PLoS One 2016;11:e0155231.

8. Hemeda H, Giebel B, Wagner W. Evaluation of human platelet lysate versus fetal bovine serum for culture of mesenchymal stromal cells. Cytotherapy 2014;16:170-180.

9. Haque N, Kasim NH, Rahman MT. Optimization of pre-transplantation conditions to enhance the efficacy of mesenchymal stem cells. Int J Biol Sci 2015;11:324-334.

10. Jung S, Sen A, Rosenberg L, Behie LA. Human mesenchymal stem cell culture: rapid and efficient isolation and expansion in a defined serumfree medium. J Tissue Eng Regen Med 2012;6:391-403.

11. Stehlik D, Pytlik R, Rychtrmocova H, Kideryova L, Vesela R, Kopecny $Z$, et al.. Xenogeneic protein-free cultivation of mesenchymal stromal cells - towards clinical applications. Folia Biol (Praha) 2012;58:106-114.

12. Fekete N, Gadelorge M, Furst D, Maurer C, Dausend J, FleuryCappellesso $\mathrm{S}$, et al.. Platelet lysate from whole blood-derived pooled platelet concentrates and apheresis-derived platelet concentrates for the isolation and expansion of human bone marrow mesenchymal stromal cells: production process, content and identification of active components. Cytotherapy 2012;14:540-554.

13. Fekete N, Rojewski MT, Furst $D$, Kreja L, Ignatius $A$, Dausend J, et al.. GMP-compliant isolation and large-scale expansion of bone marrowderived MSC. PLoS One 2012;7:e43255.

14. Fekete N, Rojewski MT, Lotfi R, Schrezenmeier H. Essential components for ex vivo proliferation of mesenchymal stromal cells. Tissue Eng Part C Methods 2014;20:129-139.

15. Jonsdottir-Buch $S M$, Sigurgrimsdottir $H$, Lieder $R$, Sigurjonsson OE. Expired and pathogen-inactivated platelet concentrates support differentiation and immunomodulation of mesenchymal stromal cells in culture. Cell Transplant 2015;24:1545-1554.

16. Mannello $F$, Tonti GA. Concise review: no breakthroughs for human mesenchymal and embryonic stem cell culture: conditioned medium, feeder layer, or feeder-free; medium with fetal calf serum, human serum, or enriched plasma; serum-free, serum replacement nonconditioned medium, or ad hoc formula? All that glitters is not gold! Stem Cells 2007;25:1603-1699.

17. Antoninus AA, Widowati W, Wijaya L, Agustina D, Puradisastra S, Sumitro $S B$, et al.. Human platelet lysate enhances the proliferation of Wharton's jelly-derived mesenchymal stem cells. Biomarkers and Genomic Med 2015;7:87-97.

18. Castren $E$, Sillat $T, 0 j a ~ S$, Noro A, Laitinen A, Konttinen YT, et al.. Osteogenic differentiation of mesenchymal stromal cells in twodimensional and three-dimensional cultures without animal serum. Stem Cell Res Ther 2015;6:167.

19. Muraglia A, Ottonello C, Spano R, Dozin B, Strada P, Grandizio M, et al.. Biological activity of a standardized freeze-dried platelet derivative to be used as cell culture medium supplement. Platelets 2014;25:211-220.

20. Schallmoser K, Strunk D. Preparation of pooled human platelet lysate (pHPL) as an efficient supplement for animal serum-free human stem cell cultures. J Vis Exp 2009;30:1-4.

21. Stute N, Holtz K, Bubenheim M, Lange C, Blake F, Zander AR. Autologous serum for isolation and expansion of human mesenchymal stem cells for clinical use. Exp Hematol 2004;32:1212-1225.

22. Murphy MB, Blashki D, Buchanan RM, Yazdi IK, Ferrari M, Simmons PJ, et al.. Adult and umbilical cord blood-derived platelet-rich plasma for mesenchymal stem cell proliferation, chemotaxis, and cryopreservation. Biomaterials 2012;33:5308-5316.

23. Castiglia S, Mareschi K, Labanca L, Lucania G, Leone M, Sanavio F, et al.. Inactivated human platelet lysate with psoralen: a new perspective for mesenchymal stromal cell production in Good Manufacturing Practice conditions. Cytotherapy 2014;16:750-763.

24. Bieback $K$, Ha VA, Hecker $A$, Grassl M, Kinzebach $S$, Solz $H$, et al.. Altered gene expression in human adipose stem cells cultured with fetal bovine serum compared to human supplements. Tissue Eng Part A 2010;16:3467-3484. 
25. Pham PV, Vu NB, Pham VM, Truong NH, Pham TL, Dang LT, et al.. Good manufacturing practice-compliant isolation and culture of human umbilical cord blood-derived mesenchymal stem cells. J Transl Med 2014;12:56.

26. Arksey $\mathrm{H}$, O'Malley L. Scoping studies: towards a methodological framework. Int J Soc Res Methodol 2005;8:19-32.

27. Rizk M, Monaghan $M$, Shorr $R$, Kekre N, Bredeson CN, Allan DS. Heterogeneity in studies of mesenchymal stromal cells to treat or prevent graft-versus-host disease: a scoping review of the evidence. Biol Blood Marrow Transplant 2016;22:1416-1423.

28. Marx RE. Platelet-rich plasma (PRP): what is PRP and what is not PRP? Implant Dent 2001;10:225-228.

29. Bieback $K$, Hecker A, Kocaomer A, Lannert $H$, Schallmoser K, Strunk $D$, et al.. Human alternatives to fetal bovine serum for the expansion of mesenchymal stromal cells from bone marrow. Stem Cells 2009;27:2331-2341.

30. Cheng MT, Liu CL, Chen TH, Lee OK. Optimization of culture conditions for stem cells derived from human anterior cruciate ligament and bone marrow. Cell Transplant 2014;23:791-803.

31. Jung $S$, Sen $A$, Rosenberg $L$, Behie LA. Identification of growth and attachment factors for the serum-free isolation and expansion of human mesenchymal stromal cells. Cytotherapy 2010;12:637-657.

32. Dolley-Sonneville PJ, Romeo LE, Melkoumian ZK. Synthetic surface for expansion of human mesenchymal stem cells in xeno-free, chemically defined culture conditions. PLoS One 2013;8:e70263.

33. Mark P, Kleinsorge M, Gaebel R, Lux CA, Toelk A, Pittermann E, et al.. Human mesenchymal stem cells display reduced expression of cd105 after culture in serum-free medium. Stem Cells Int 2013;2013:698076.

34. Reza AT, Nicoll SB. Serum-free, chemically defined medium with TGF-beta(3) enhances functional properties of nucleus pulposus cellladen carboxymethylcellulose hydrogel constructs. Biotechnol Bioeng 2010;105:384-395.

35. Sato Y, Wakitani S, Takagi M. Xeno-free and shrinkage-free preparation of scaffold-free cartilage-like disc-shaped cell sheet using human bone marrow mesenchymal stem cells. J Biosci Bioeng 2013;116:734-739.

36. Tan KY, Teo KL, Lim JF, Chen AK, Choolani M, Reuveny $S$, et al.. Serumfree media formulations are cell line-specific and require optimization for microcarrier culture. Cytotherapy 2015;17:1152-1165.

37. Trubiani 0, Piattelli A, Gatta V, Marchisio M, Diomede F, D'Aurora $M$, et al.. Assessment of an efficient xeno-free culture system of human periodontal ligament stem cells. Tissue Eng Part C Methods 2015;21:52-64.

38. Schallmoser K, Rohde E, Bartmann C, Obenauf AC, Reinisch A, Strunk D. Platelet-derived growth factors for GMP-compliant propagation of mesenchymal stromal cells. Biomed Mater Eng 2009;19:271-276.

39. Jung S, Panchalingam KM, Rosenberg L, Behie LA. Ex vivo expansion of human mesenchymal stem cells in defined serum-free media. Stem Cells Int 2012;2012:123030.

40. Jung S, Panchalingam KM, Wuerth RD, Rosenberg L, Behie LA. Largescale production of human mesenchymal stem cells for clinical applications. Biotechnol Appl Biochem 2012;59:106-120.

41. Cholewa D, Stiehl T, Schellenberg A, Bokermann G, Joussen S, Koch $\mathrm{C}$, et al.. Expansion of adipose mesenchymal stromal cells is affected by human platelet lysate and plating density. Cell Transplant 2011;20:1409-1422.

42. Koellensperger E, Bollinger N, Dexheimer V, Gramley F, Germann G, Leimer U. Choosing the right type of serum for different applications of human adipose tissue-derived stem cells: influence on proliferation and differentiation abilities. Cytotherapy 2014;16:789-799.

43. Shih DT, Chen JC, Chen WY, Kuo YP, Su CY, Burnouf T. Expansion of adipose tissue mesenchymal stromal progenitors in serum-free medium supplemented with virally inactivated allogeneic human platelet lysate. Transfusion 2011;51:770-778.

44. Paula AC, Martins TM, Zonari A, Frade SP, Angelo PC, Gomes DA, et al.. Human adipose tissue-derived stem cells cultured in xeno-free culture condition enhance c-MYC expression increasing proliferation but bypassing spontaneous cell transformation. Stem Cell Res Ther 2015;6:76.

45. Kyllonen L, Haimi S, Mannerstrom B, Huhtala H, Rajala KM, Skottman
$H$, et al.. Effects of different serum conditions on osteogenic differentiation of human adipose stem cells in vitro. Stem Cell Res Ther 2013;4:17

46. Oikonomopoulos $A$, van Deen WK, Manansala AR, Lacey PN, Tomakili TA, Ziman A, et al.. Optimization of human mesenchymal stem cell manufacturing: the effects of animal/xeno-free media. Sci Rep 2015;5:16570.

47. Govindasamy V, Ronald VS, Abdullah AN, Ganesan Nathan KR, Aziz ZA, Abdullah $M$, et al.. Human platelet lysate permits scale-up of dental pulp stromal cells for clinical applications. Cytotherapy $2011 ; 13: 1221-$ 1233.

48. Pisciotta A, Riccio M, Carnevale G, Beretti F, Gibellini L, Maraldi T, et al.. Human serum promotes osteogenic differentiation of human dental pulp stem cells in vitro and in vivo. PLoS One 2012;7:e50542.

49. Budiyanti E, Liem I, Pawitan J, Wulandari D, Jamaan T, Sumapradja K. Umbilical cord derived mesenchymal stem cell proliferation in various platelet rich plasma and xeno-material containing medium. Int J Res Pharm Sci 2015;6:7-13.

50. Hatlapatka T, Moretti P, Lavrentieva A, Hass R, Marquardt N, Jacobs R, et al.. Optimization of culture conditions for the expansion of umbilical cord-derived mesenchymal stem or stromal cell-like cells using xenofree culture conditions. Tissue Eng Part C Methods 2011;17:485-493.

51. Hartmann I, Hollweck T, Haffner S, Krebs M, Meiser B, Reichart B, et al.. Umbilical cord tissue-derived mesenchymal stem cells grow best under GMP-compliant culture conditions and maintain their phenotypic and functional properties. J Immunol Methods 2010;363:80-89.

52. Luzzani C, Neiman G, Garate X, Questa M, Solari C, Fernandez Espinosa $D$, et al.. A therapy-grade protocol for differentiation of pluripotent stem cells into mesenchymal stem cells using platelet lysate as supplement. Stem Cell Res Ther 2015;6:6.

53. Martins TM, de Paula AC, Gomes DA, Goes AM. Alkaline phosphatase expression/activity and multilineage differentiation potential are the differences between fibroblasts and orbital fat-derived stem cells--a study in animal serum-free culture conditions. Stem Cell Rev 2014;10:697-711.

54. Gottipamula S, Sharma A, Krishnamurthy S, Majumdar AS, Seetharam $\mathrm{RN}$. Human platelet lysate is an alternative to fetal bovine serum for large-scale expansion of bone marrow-derived mesenchymal stromal cells. Biotechnol Lett 2012;34:1367-1374.

55. Laitinen A, Oja S, Kilpinen L, Kaartinen $T$, Moller J, Laitinen $S$, et al.. $A$ robust and reproducible animal serum-free culture method for clinical-grade bone marrow-derived mesenchymal stromal cells. Cytotechnology 2015;68:891-906.

56. Felka T, Schafer R, De Zwart P, Aicher WK. Animal serum-free expansion and differentiation of human mesenchymal stromal cells. Cytotherapy 2010;12:143-153.

57. Li CY, Wu XY, Tong JB, Yang XX, Zhao JL, Zheng QF, et al.. Comparative analysis of human mesenchymal stem cells from bone marrow and adipose tissue under xeno-free conditions for cell therapy. Stem Cell Res Ther 2015;6:55.

58. Schallmoser K, Strunk D. Generation of a pool of human platelet lysate and efficient use in cell culture. Methods Mol Biol 2013;946:349-362.

59. Chevallier N, Anagnostou F, Zilber S, Bodivit G, Maurin S, Barrault A, et al.. Osteoblastic differentiation of human mesenchymal stem cells with platelet lysate. Biomaterials 2010;31:270-278.

60. Capelli C, Domenghini M, Borleri G, Bellavita P, Poma R, Carobbio $A$, et al.. Human platelet lysate allows expansion and clinical grade production of mesenchymal stromal cells from small samples of bone marrow aspirates or marrow filter washouts. Bone Marrow Transplant 2007;40:785-791.

61. Lohmann M, Walenda G, Hemeda $H$, Joussen $S$, Drescher $W$, Jockenhoevel $\mathrm{S}$, et al.. Donor age of human platelet lysate affects proliferation and differentiation of mesenchymal stem cells. PLoS One 2012;7:e37839.

62. Doucet C, Ernou I, Zhang Y, Llense JR, Begot L, Holy $X$, et al.. Platelet lysates promote mesenchymal stem cell expansion: a safety substitute for animal serum in cell-based therapy applications. J Cell Physiol 2005;205:228-236

63. Bernardi M, Albiero E, Alghisi A, Chieregato K, Lievore C, Madeo D, et 
al.. Production of human platelet lysate by use of ultrasound for ex vivo expansion of human bone marrow-derived mesenchymal stromal cells. Cytotherapy 2013;15:920-929.

64. Blande IS, Bassaneze V, Lavini-Ramos C, Fae KC, Kalil J, Miyakawa AA, et al.. Adipose tissue mesenchymal stem cell expansion in animal serumfree medium supplemented with autologous human platelet lysate. Transfusion 2009;49:2680-2685.

65. Jenhani F, Durand V, Ben Azouna N, Thallet S, Ben Othmen T, Bejaoui $\mathrm{M}$, et al.. Human cytokine expression profile in various conditioned media for in vitro expansion bone marrow and umbilical cord blood immunophenotyped mesenchymal stem cells. Transplant Proc 2011;43:639-643.

66. Iudicone P, Fioravanti D, Bonanno G, Miceli M, Lavorino C, Totta P, et al.. Pathogen-free, plasma-poor platelet lysate and expansion of human mesenchymal stem cells. J Transl Med 2014;12:28.

67. Laner-Plamberger S, Lener T, Schmid D, Streif DA, Salzer T, Oller $M$, et al.. Mechanical fibrinogen-depletion supports heparin-free mesenchymal stem cell propagation in human platelet lysate. J Transl Med 2015;13:354.

68. Griffiths S, Baraniak PR, Copland IB, Nerem RM, McDevitt TC. Human platelet lysate stimulates high-passage and senescent human multipotent mesenchymal stromal cell growth and rejuvenation in vitro. Cytotherapy 2013;15:1469-1483

69. Horn P, Bokermann G, Cholewa D, Bork S, Walenda T, Koch C, et al.. Impact of individual platelet lysates on isolation and growth of human mesenchymal stromal cells. Cytotherapy 2010;12:888-898.

70. Zaky SH, Ottonello A, Strada P, Cancedda R, Mastrogiacomo M. Platelet lysate favours in vitro expansion of human bone marrow stromal cells for bone and cartilage engineering. J Tissue Eng Regen Med 2008;2:472-481.

71. Flemming A, Schallmoser $K$, Strunk D, Stolk M, Volk HD, Seifert M. Immunomodulative efficacy of bone marrow-derived mesenchymal stem cells cultured in human platelet lysate. J Clin Immunol 2011;31:1143-1156

72. Reinisch A, Bartmann C, Rohde $E_{1}$ Schallmoser K, Bjelic-Radisic V, Lanzer $\mathrm{G}$, et al.. Humanized system to propagate cord blood-derived multipotent mesenchymal stromal cells for clinical application. Regen Med 2007:2:371-382.

73. Abdelrazik H, Spaggiari GM, Chiossone L, Moretta L. Mesenchymal stem cells expanded in human platelet lysate display a decreased inhibitory capacity on T- and NK-cell proliferation and function. Eur J Immunol 2011;41:3281-3290.

74. Shanskii YD, Sergeeva NS, Sviridova IK, Kirakozov MS, Kirsanova VA, Akhmedova SA, et al.. Human platelet lysate as a promising growthstimulating additive for culturing of stem cells and other cell types. Bull Exp Biol Med 2013;156:146-151.

75. Schallmoser K, Bartmann C, Rohde E, Reinisch A, Kashofer K, Stadelmeyer $E_{\text {, et }}$ al.. Human platelet lysate can replace fetal bovine serum for clinical-scale expansion of functional mesenchymal stromal cells. Transfusion 2007;47:1436-1446.

76. Xia W, Li H, Wang Z, Xu R, Fu Y, Zhang $X$, et al.. Human platelet lysate supports ex vivo expansion and enhances osteogenic differentiation of human bone marrow-derived mesenchymal stem cells. Cell Biol Int 2011;35:639-643.

77. Salvade A, Della Mina P, Gaddi D, Gatto F, Villa A, Bigoni M, et al.. Characterization of platelet lysate cultured mesenchymal stromal cells and their potential use in tissue-engineered osteogenic devices for the treatment of bone defects. Tissue Eng Part C Methods 2010;16:201214.

78. Lange C, Cakiroglu F, Spiess AN, Cappallo-Obermann H, Dierlamm J, Zander AR. Accelerated and safe expansion of human mesenchymal stromal cells in animal serum-free medium for transplantation and regenerative medicine. J Cell Physiol 2007;213:18-26.

79. Yamauchi T, Saito H, Ito M, Shichinohe H, Houkin K, Kuroda S. Platelet lysate and granulocyte-colony stimulating factor serve safe and accelerated expansion of human bone marrow stromal cells for stroke therapy. Transl Stroke Res 2014;5:701-710.

80. Shahdadfar A, Fronsdal K, Haug T, Reinholt FP, Brinchmann JE. In vitro expansion of human mesenchymal stem cells: choice of serum is a determinant of cell proliferation, differentiation, gene expression, and transcriptome stability. Stem Cells 2005;23:1357-1366

81. Gregory CA, Reyes E, Whitney MJ, Spees JL. Enhanced engraftment of mesenchymal stem cells in a cutaneous wound model by culture in allogenic species-specific serum and administration in fibrin constructs. Stem Cells 2006;24:2232-2243.

82. Le Blanc K, Samuelsson H, Lonnies L, Sundin M, Ringden O. Generation of immunosuppressive mesenchymal stem cells in allogeneic human serum. Transplantation 2007;84:1055-1059.

83. Pawitan J, Wulandari D, Suryani D, Damayanti L, Purwoko R, Liem I. Flow cytometry analysis of adipose tissue-derived stem cells that were cultured in various media. Int J Pharm Tech Res 2013;5:1301-1306.

84. Kishimoto $S$, Hattori H, Nakamura $S$, Amano $Y$, Kanatani $Y$, Tanaka $Y$, et al.. Expansion and characterization of human bone marrow-derived mesenchymal stem cells cultured on fragmin/protamine microparticlecoated matrix with fibroblast growth factor-2 in low serum medium. Tissue Eng Part C Methods 2009;15:523-527.

85. Aldahmash $A$, Haack-Sorensen $M, A l-N b a h e e n ~ M$, Harkness $L$, Abdallah $B M$, Kassem M. Human serum is as efficient as fetal bovine serum in supporting proliferation and differentiation of human multipotent stromal (mesenchymal) stem cells in vitro and in vivo. Stem Cell Rev 2011;7:860-868.

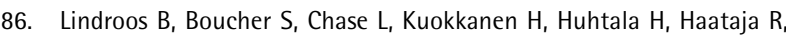
et al.. Serum-free, xeno-free culture media maintain the proliferation rate and multipotentiality of adipose stem cells in vitro. Cytotherapy 2009;11:958-972.

87. Lindroos $B$, Aho $K L$, Kuokkanen $H$, Raty $S$, Huhtala $H$, Lemponen $R$, et al.. Differential gene expression in adipose stem cells cultured in allogeneic human serum versus fetal bovine serum. Tissue Eng Part $A$ 2010;16:2281-2294.

88. Pytlik R, Stehlik D, Soukup T, Kalbacova M, Rypacek F, Trc T, et al.. The cultivation of human multipotent mesenchymal stromal cells in clinical grade medium for bone tissue engineering. Biomaterials 2009;30:3415-3427.

89. Kocaoemer A, Kern $S$, Kluter $H$, Bieback K. Human $A B$ serum and thrombin-activated platelet-rich plasma are suitable alternatives to fetal calf serum for the expansion of mesenchymal stem cells from adipose tissue. Stem Cells 2007;25:1270-1278.

90. Kruger JP, Hondke S, Endres M, Pruss A, Siclari A, Kaps C. Human platelet-rich plasma stimulates migration and chondrogenic differentiation of human subchondral progenitor cells. J Orthop Res 2012;30:845-852.

91. Pawitan J, Feroniasanti L, Kispa T, Dilogo I, Fasha I, Kurniawati T, et al.. Simple method to isolate mesenchymal stem cells from bone marrow using xeno-free material: A preliminary study. Int J Pharm Tech Re 2015;7:354-359.

92. Goedecke A, Wobus M, Krech M, Munch N, Richter K, Holig K, et al.. Differential effect of platelet-rich plasma and fetal calf serum on bone marrow-derived human mesenchymal stromal cells expanded in vitro. J Tissue Eng Regen Med 2011;5:648-654.

93. Kishimoto $S$, Ishihara $M$, Mori $Y$, Takikawa $M$, Hattori $H$, Nakamura $S$, et al.. Effective expansion of human adipose-derived stromal cells and bone marrow-derived mesenchymal stem cells cultured on a fragmin/ protamine nanoparticles-coated substratum with human platelet-rich plasma. J Tissue Eng Regen Med 2013;7:955-964.

94. Ichiyanagi T, Anabuki K, Nishijima Y, Ono H. Isolation of mesenchyma stem cells from bone marrow wastes of spinal fusion procedure (TLIF) for low back pain patients and preparation of bone dusts for transplantable autologous bone graft with a serum glue. Biosci Trends 2010;4:110-118.

95. Muller I, Kordowich S, Holzwarth C, Spano C, Isensee G, Staiber A, et al.. Animal serum-free culture conditions for isolation and expansion of multipotent mesenchymal stromal cells from human BM. Cytotherapy 2006:8:437-444.

96. Behnia $H$, Khojasteh $A$, Soleimani M, Tehranchi A, Atashi A. Repair of alveolar cleft defect with mesenchymal stem cells and platelet derived growth factors: a preliminary report. J Craniomaxillofac Surg 2012;40:2-7

97. Shayesteh YS, Khojasteh A, Soleimani M, Alikhasi M, Khoshzaban A 
Ahmadbeigi N. Sinus augmentation using human mesenchymal stem cells loaded into a beta-tricalcium phosphate/hydroxyapatite scaffold. Oral Surg Oral Med Oral Pathol Oral Radiol Endod 2008;106:203-209.

98. Sandor GK, Tuovinen VJ, Wolff J, Patrikoski M, Jokinen J, Nieminen E, et al.. Adipose stem cell tissue-engineered construct used to treat large anterior mandibular defect: a case report and review of the clinical application of good manufacturing practice-level adipose stem cells for bone regeneration. J Oral Maxillofac Surg 2013;71:938-950.

99. Behnia $H$, Khojasteh $A$, Soleimani $M$, Tehranchi $A$, Khoshzaban $A$ Keshel SH, et al.. Secondary repair of alveolar clefts using human mesenchymal stem cells. Oral Surg Oral Med Oral Pathol Oral Radiol Endod 2009;108:e1-6.

100. Lucchini G, Introna M, Dander E, Rovelli A, Balduzzi A, Bonanomi S, et al.. Platelet-lysate-expanded mesenchymal stromal cells as a salvage therapy for severe resistant graft-versus-host disease in a pediatric population. Biol Blood Marrow Transplant 2010;16:1293-1301.

101. Centeno CJ, Schultz JR, Cheever M, Freeman M, Faulkner S, Robinson $B$, et al.. Safety and complications reporting update on the re-implantation of culture-expanded mesenchymal stem cells using autologous platelet lysate technique. Curr Stem Cell Res Ther 2011;6:368-378.

102. Lataillade JJ, Doucet $C_{1}$ Bey $E_{1}$ Carsin $H_{\text {, Huet }} C_{1}$ Clairand I, et al.. New approach to radiation burn treatment by dosimetry-guided surgery combined with autologous mesenchymal stem cell therapy. Regen Med 2007;2:785-794.

103. Bieback K. Platelet lysate as replacement for fetal bovine serum in mesenchymal stromal cell cultures. Transfus Med Hemother 2013;40:326-335.

104. Gottipamula S, Ashwin KM, Muttigi MS, Kannan S, Kolkundkar U, Seetharam RN. Isolation, expansion and characterization of bone marrow-derived mesenchymal stromal cells in serum-free conditions. Cell Tissue Res 2014;356:123-135.

105. Riordan NH, Madrigal M, Reneau J, de Cupeiro K, Jimenez N, Ruiz $S$, et al.. Scalable efficient expansion of mesenchymal stem cells in xeno free media using commercially available reagents. J Transl Med 2015;13:232.

106. Venugopal $P$, Balasubramanian S, Majumdar AS, Ta M. Isolation, characterization, and gene expression analysis of Wharton's jellyderived mesenchymal stem cells under xeno-free culture conditions. Stem Cells Cloning 2011;4:39-50.

107. Trojahn Kolle SF, Oliveri RS, Glovinski PV, Kirchhoff M, Mathiasen $A B$, Elberg JJ, et al.. Pooled human platelet lysate versus fetal bovine serum-investigating the proliferation rate, chromosome stability and angiogenic potential of human adipose tissue-derived stem cells intended for clinical use. Cytotherapy 2013;15:1086-1097.

108. Capelli C, Gotti E, Morigi M, Rota C, Weng L, Dazzi F, et al.. Minimally manipulated whole human umbilical cord is a rich source of clinical- grade human mesenchymal stromal cells expanded in human platelet lysate. Cytotherapy 2011;13:786-801

109. Crespo-Diaz R, Behfar A, Butler GW, Padley DJ, Sarr MG, Bartunek J, et al.. Platelet lysate consisting of a natural repair proteome supports human mesenchymal stem cell proliferation and chromosomal stability. Cell Transplant 2011;20:797-811.

110. Rauch C, Feifel E, Amann EM, Spotl HP, Schennach H, Pfaller W, et al.. Alternatives to the use of fetal bovine serum: human platelet lysates as a serum substitute in cell culture media. ALTEX 2011;28:305-316.

111. Vogel JP, Szalay K, Geiger F, Kramer M, Richter W, Kasten P. Plateletrich plasma improves expansion of human mesenchymal stem cells and retains differentiation capacity and in vivo bone formation in calcium phosphate ceramics. Platelets 2006;17:462-469.

112. Harrison P, Cramer EM. Platelet alpha-granules. Blood Rev 1993;7:5262.

113. Poloni A, Maurizi G, Serrani F, Mancini S, Discepoli G, Tranquilli AL, et al.. Human $A B$ serum for generation of mesenchymal stem cells from human chorionic villi: comparison with other source and other media including platelet lysate. Cell Prolif 2012;45:66-75.

114. Schallmoser K, Rohde E, Reinisch A, Bartmann C, Thaler D, Drexler C, et al.. Rapid large-scale expansion of functional mesenchymal stem cells from unmanipulated bone marrow without animal serum. Tissue Eng Part C Methods 2008;14:185-196.

115. Chisini LA, Conde MC, Alcazar JC, Silva AF, Nor JE, Tarquinio SB, et al.. Immunohistochemical Expression of TGF-beta1 and Osteonectin in engineered and $\mathrm{Ca}(\mathrm{OH}) 2$-repaired human pulp tissues. Braz Oral Res 2016;30:e93.

116. Conde MC, Chisini LA, Grazioli G, Francia A, Carvalho RV, Alcazar JC, et al.. Does cryopreservation affect the biological properties of stem cells from dental tissues? a systematic review. Braz Dent J 2016;27:633-640.

117. Hemeda $H$, Kalz J, Walenda G, Lohmann M, Wagner W. Heparin concentration is critical for cell culture with human platelet lysate Cytotherapy 2013;15:1174-1181.

118. Mojica-Henshaw MP, Jacobson P, Morris J, Kelley L, Pierce J, Boyer M, et al.. Serum-converted platelet lysate can substitute for fetal bovine serum in human mesenchymal stromal cell cultures. Cytotherapy 2013;15:1458-1468.

119. Dimri GP, Lee $X$, Basile G, Acosta M, Scott G, Roskelley $C$, et al.. A biomarker that identifies senescent human cells in culture and in aging skin in vivo. Proc Natl Acad Sci U S A 1995;92:9363-9367.

120. Rojewski MT, Fekete N, Baila S, Nguyen K, Furst D, Antwiler D, et al.. GMP-compliant isolation and expansion of bone marrow-derived MSCs in the closed, automated device quantum cell expansion system. Cell Transplant 2013;22:1981-2000.
Received April 22, 2017 Accepted October 16, 2017 